\title{
Quantitative aspects of intestinal fat absorption in young pigs
}

\author{
By C. P. FREEMAN, D. E. NOAKES, E. F. ANNISON AND K. J. HILL \\ Unilever Research Laboratory, Colworth House, Sharnbrook, Bedford
}

(Received 23 April г968-Accepted I9 $¥$ fuly 1968)

\begin{abstract}
I. The uptake of lipid by the small intestine of the pig was examined by the perfusion of a segment of the jejunum with radioactively labelled lipid in vivo. The rate at which lipid was presented to the small intestine under specific dietary regimes was also examined by means of re-entrant fistulas in the duodenum and jejunum.

2. The capacity of the small intestine to absorb micellar lipid, prepared in vitro or isolated from intestinal contents, was much in excess of the normal rate of flow of fat into the small intestine.

3. There was little uptake of lipid when emulsions of oleic acid were examined, suggesting that the absorption of particulate fat is probably of little importance in pigs.

4. No specificity in the removal of fatty acids from their mixed micellar solutions was observed.
\end{abstract}

The importance of micelle formation during the digestion and absorption of fats in man is now well established (Hofmann \& Borgström, 1962, I964; Borgström, I967), but there is little information on the quantitative significance of this route of absorption either in man or in other species. We have previously demonstrated the occurrence of micellar lipid in equilibrium with emulsified fat in the contents of the small intestine of the pig after the ingestion of fat (Freeman, Annison, Noakes \& Hill, I967), and have shown that the composition of the micellar lipid is closely similar to that reported for man (Hofmann \& Borgström, 1964). The present studies on surgically prepared pigs were therefore undertaken to assess the relative importance of micellar and particulate lipid absorption from the small intestine, particularly in relation to the rate at which lipid is presented to the small intestine under specific dietary regimes.

\section{EXPERIMENTAL}

Experimental animals

Two Large White and two Large White $\times$ Wessex pigs, ro-I4 weeks old and of $25-40 \mathrm{~kg}$ live weight, were used. They were housed in individual cages and remained in them during experiments.

\section{Diet and feeding regime}

The pigs were fed a standard ration (containing $17.6 \%$ protein, $2.7 \%$ fat and $3.3 \%$ fibre) throughout the experimental period. In some experiments a diet containing Io $\%$ fat, prepared by adding lard to the above ration, was given to the pigs. In studies on intestinal flow the diet was given either as a single meal $(400 \mathrm{~g})$ on the morning of the experiment after an overnight fast, or was offered $a d l i b$. Water was freely available, and its intake recorded. 


\section{Surgical preparations}

Details of anaesthesia and the preparation of re-entrant fistulas were as described by Noakes \& Hill (to be published). Single re-entrant fistulas were prepared in the duodenal (pig I23) or jejunal (pig I 19) region of the small intestine. Cannulas were exteriorized through the body wall in the region of the right flank and continuity of flow was established by means of Perspex elbow pieces and polyvinyl tubing.

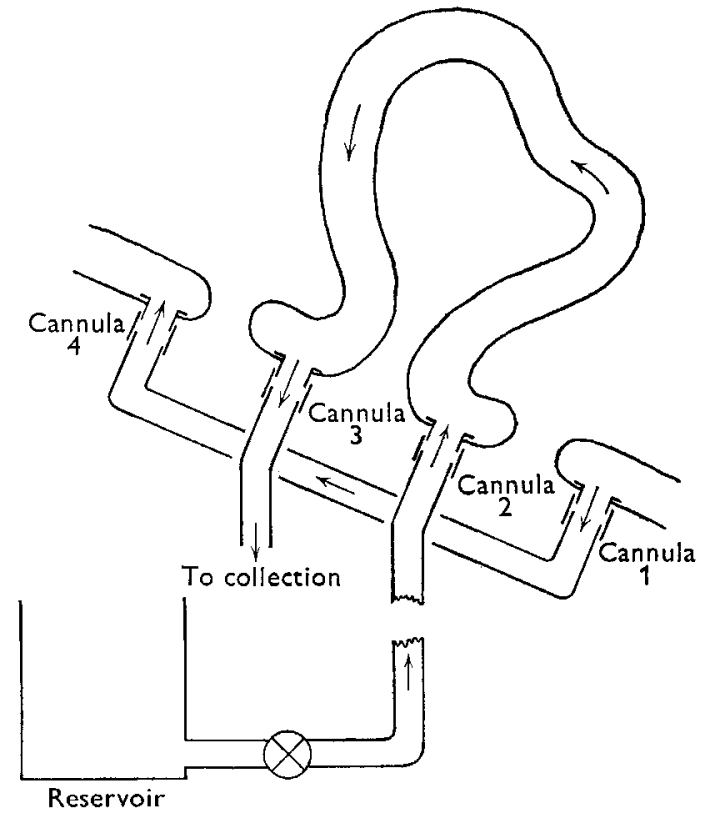

Fig. I. Arrangement for perfusion of an isolated intestinal loop using two jejunal re-entrant fistulas.

Double re-entrant fistulas were prepared in two pigs, pig 140 ( $35 \mathrm{~kg}$; age, I4 weeks) and pig 146 ( $30 \mathrm{~kg}$; age, 12 weeks) for the absorption experiments. The fistulas were in the jejunal region, and in both animals the length of intestine between cannulas 2 and 3 (Fig. I) was $30-35 \mathrm{~cm}$, and was approximately $3 \mathrm{~m}$ from the pyloric sphincter. Apart from the perfusion periods, normal flow of digesta was maintained through the loop by connecting cannulas I with 2 , and 3 with 4 . Occasionally, after frequent experimental usage, slight leakage of fluid occurred between the fistula tract and the shaft of the cannula.

\section{Experimental procedure}

Rates of flow of digesta were measured in pigs prepared with single re-entrant fistulas by disconnecting the cannulas and attaching lengths of lightweight plastic tubing to the elbow pieces. Contents were allowed to flow from the cranial cannula and were collected in a graduated measuring cylinder. Portions of $50 \mathrm{ml}$ or $100 \mathrm{ml}$ were collected, and after sampling were returned immediately to the small intestine 
through the caudal cannula. The hourly flow rate was obtained by combining the portions obtained in that time.

Absorption of lipid from a loop of intestine was examined by perfusing the loop with radioactively labelled lipid in either micellar or emulsified form, an open-ended system being used (Fig. I). Several hours before the experiment the cannulas were disconnected and cannula I was connected to cannula 4, thus isolating a segment of jejunum between cannulas 2 and 3 , whilst maintaining normal flow through the remainder of the small intestine. The loop was allowed to drain freely and, immediately before perfusion, was washed out with normal saline at $37^{\circ}$. Labelled perfusate was pumped through the loop at a constant rate from a reservoir maintained at $40^{\circ}$ and the efflux from the loop collected in a measuring cylinder. Samples were taken from the reservoir at zero time for determination of the concentration of lipid entering the loop, and subsequently sequential samples $(3 \mathrm{ml})$ of the efflux were taken from the posterior cannula. After centrifuging the samples to remove mucus, portions were taken for the assay of radioactivity and inert marker, as described below.

\section{Radioactive materials}

Tritiated fatty acids and $\left[{ }^{14} \mathrm{C}\right]$-labelled fatty acids were obtained from the Radiochemical Centre, Amersham.

\section{Preparation of perfusates}

Micellar lipid perfusates were prepared by solubilizing the labelled fatty acids by shaking at about half their saturation levels in $0.5 \%$ sodium glycodeoxycholate in phosphate buffer ( $\mathrm{pH} \mathrm{6.3)}$ for $\mathrm{I} h$ at $37^{\circ}$. The clear micellar solutions were held at this temperature until use.

The physiological micellar solution was isolated from a donor pig with a duodenal fistula. The animal was fed $\left[{ }^{3} \mathrm{H}\right]$ oleic acid $(\mathrm{x} \mathrm{mc}$ ) carried on $5 \circ \mathrm{g}$ of the high-fat ration, and contents were collected from the fistula starting about 30 min after feeding. After heating at $70^{\circ}$ for Io min to inactivate lipase the contents were centrifuged at $75000 \mathrm{~g}$ for $\mathrm{I} 8 \mathrm{~h}$ at room temperature. The clear mid-fraction was drawn off from each centrifuge tube and bulked to yield a micellar lipid solution $(4.6 \mathrm{mg}, 10.3 \mathrm{nc} / \mathrm{ml})$.

The $\left[{ }^{1-14} \mathrm{C}\right]$ oleic acid emulsion $(50 \mathrm{nc} / \mathrm{mg}$ per $\mathrm{ml}$ ) was prepared by ultrasonication in phosphate buffer for ro min, lecithin being added at a level of $5 \%$ of the oleic acid to enhance emulsion stability. The emulsions were examined by phase-contrast microscopy, an eyepiece and stage micrometer being used to estimate particle size. The particles in the sonicated emulsions were distributed in three main groups; the largest group contained particles of $0.5 \mu \mathrm{m}$ and less; a smaller group contained particles of I $-2 \mu \mathrm{m}$, and a number of particles of $5 \mu \mathrm{m}$ and above were observed.

A non-absorbable marker, polyethylene glycol 4000 (PEG; British Drug Houses Ltd, Poole) was added to each perfusate at a concentration of $7.5 \mathrm{mg} / \mathrm{ml}$, to allow correction for changes in concentration occurring in the loop.

\section{Analytical methods}

The lipid content of digesta was determined by extracting the intestinal contents in the solvent system described by Blankenhorn \& Ahrens (1955). The upper phase was 
removed, the solvent removed in vacuo, and the residue dissolved in light petroleum and dried over anhydrous sodium sulphate. The extract was evaporated to dryness under a stream of nitrogen, and the residue weighed.

The radioactivity of perfusates was assayed by liquid scintillation counting (Packard Tri-Carb Liquid Scintillation Spectrometer, Model 4322), using an external standard of ${ }^{226} \mathrm{Ra}$ to correct for quenching. Aqueous samples of perfusate ( $\mathrm{I} \mathrm{ml}$ ) were mixed with $\mathrm{I} 5 \mathrm{ml}$ of a mixture $(2: \mathrm{I}, \mathrm{v} / \mathrm{v})$ of toluene containing $0.4 \% 2,5$-diphenyloxazole (PPO; Packard Instruments Ltd, Wembley) and a non-ionic detergent (Triton X-Ioo, Lennig Chemical Co., Jarrow-on-Tyne), which gave a single-phase system suitable for counting.

The determination of specific radioactivity (sra) of fatty acids was carried out on a gas-radiochromatograph (James \& Piper, 1963) using a $120 \times 0.4 \mathrm{~cm}$ column of polyethyleneglycol adipate (10\%) on Anakrom (Analabs, Inc., Hamden, Conn., USA) at $\mathrm{I} 75^{\circ}$.

PEG was estimated by the method of Hydén (1956), incorporating the modifications suggested by Ulyatt (1964) and Downes \& McDonald (1964). The sample was clarified with barium hydroxide and zinc sulphate (Somogyi, 1945), and after standing for $5 \mathrm{~min}$ the mixture was centrifuged at $15000 \mathrm{~g}$ for $\mathrm{IO}$ min. A sample of the filtrate was made up to $5 \mathrm{ml}$ with water. Turbidity was induced by the addition of $5 \mathrm{ml}$ of a solution containing $30 \%(\mathrm{w} / \mathrm{v})$ trichloroacetic acid and $5.9 \%(\mathrm{w} / \mathrm{v})$ barium chloride. The tubes were inverted once to mix the contents. After they had stood for $20 \mathrm{~min}$, percentage transmittance was measured at $540 \mathrm{~nm}$. A series of PEG standards was included with each batch of analyses.

\section{Calculation of lipid uptake}

The rate of uptake, $R_{x}$ of substrate $x$ (in $\mathrm{mg} / \mathrm{min}$ ) is given by the equation

$$
R_{x}=R_{1}\left(C_{1}-C_{2} \frac{m_{1}}{m_{2}}\right)
$$

where $R_{1}=$ rate of entry of perfusate $(\mathrm{ml} / \mathrm{min}), R_{2}=$ rate of exit of perfusate $(\mathrm{ml} / \mathrm{min}), C_{1}=$ concentration of substrate entering the loop $(\mathrm{mg} / \mathrm{ml}), C_{2}=$ concentration of substrate leaving the loop $(\mathrm{mg} / \mathrm{ml}), m_{1}=$ concentration of marker entering the loop $(\mathrm{mg} / \mathrm{ml})$, and $m_{2}=$ concentration of marker leaving the loop $(\mathrm{mg} / \mathrm{ml})$.

If leakage occurs, then equation ( $\mathrm{I}$ ) has to be modified by further terms, depending on the site of leakage. In practice, it is usually not possible to define whether leakage occurs exclusively at one cannula, or at both, and hence an approximation has to be made:

$$
R_{x}=C_{1} R_{1}-C_{2} R_{2}-\frac{\left(C_{1}+C_{2}\right)}{2} R_{3}
$$

where $R_{3}=$ rate of leakage of fluid.

The occurrence of leakage can be checked from the recovery of inert marker. If significant, then the rate of leakage $\left(R_{3}\right)$ can be estimated from the known rate of entry of inert marker and its measured rate of efflux. 
The extent of absorption, given by the expression

remains unaffected by leakage.

$$
\frac{C_{1}-C_{2}\left(m_{1} / m_{2}\right)}{C_{1}} \times 100
$$

\section{RESULTS}

\section{Rate of flow of digesta along the small intestine}

Duodenal flow. Two experiments were performed on pig 123 prepared with a duodenal re-entrant fistula. In each experiment the consumption of a single meal containing $10 \%$ fat resulted in a marked increase in the rate of flow of digesta from around $200 \mathrm{ml} / \mathrm{h}$ to $1000 \mathrm{ml} / \mathrm{h}$ (Fig. 2). At the same time there was an increase in the concentration of lipid in the contents resulting in an increase in the amount of lipid passing to the intestine from about $50 \mathrm{mg} / \mathrm{min}$ to a peak of $400 \mathrm{mg} / \mathrm{min}$, which was followed by a steep fall to a level which fluctuated about a mean of $100 \mathrm{mg} / \mathrm{min}$.

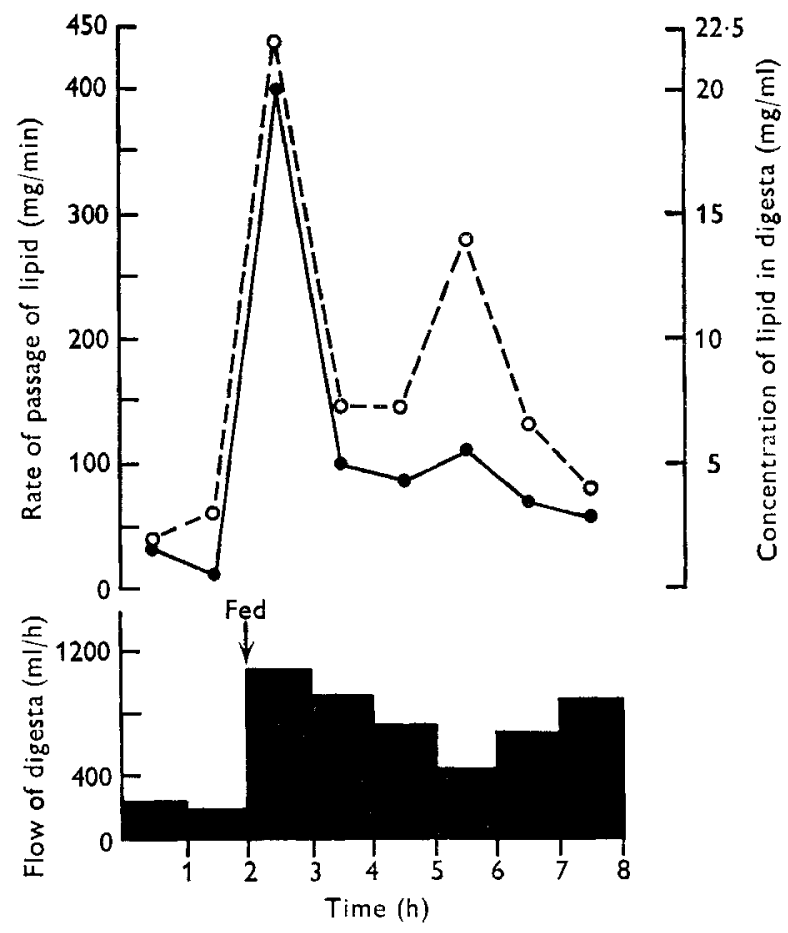

Fig. 2. Digesta flow and rate of passage of lipid in the duodenum of pig 123 . Single meal (400 g) of high-fat $(10 \%)$ diet given after overnight fast. - - , rate of passage of lipid; $\mathrm{O}---\mathrm{O}$, concentration of lipid in digesta.

fejunal flow. In two experiments when the pig was fed the standard diet ad lib., the lipid concentration in jejunal digesta was fairly constant (Fig. $3^{a}$ ). The mean lipid concentration was $2 \mathrm{mg} / \mathrm{ml}$, which gave a mean value of $20 \mathrm{mg} / \mathrm{min}$ for the amount of lipid which passed along the jejunum. When the high-fat diet was given, the concentra- 
tion was increased to about $5 \mathrm{mg} / \mathrm{ml}$ and the total flow of lipid to about $40 \mathrm{mg} / \mathrm{min}$ (Fig. $3^{b}$ ). Flow was less constant on the high-fat diet.

Four experiments were performed in which single meals (400 g) of high and low fat content were given to pig II 9 and the flow of digesta was measured over an $8 \mathrm{~h}$ period.
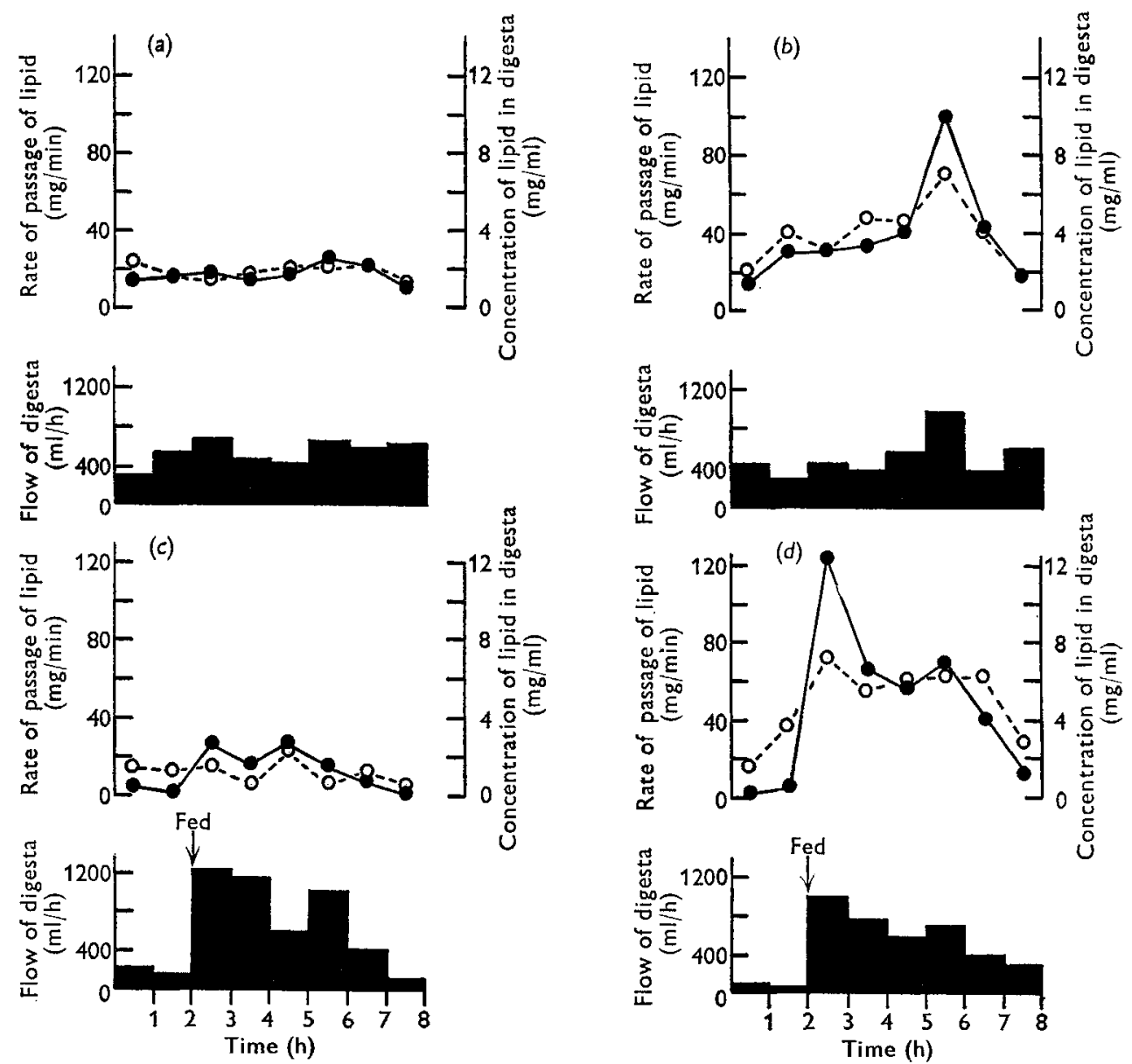

Fig. 3. Digesta flow and rate of passage of lipid in the jejunum of pig $119 .(a)$ Low-fat (2.7\%) diet, fed $a d$. lib.; (b) high-fat (10\%) diet, fed ad lib.; (c) low-fat diet, single feed (400 g) after overnight fast; $(d)$ high-fat diet, single feed $(400 \mathrm{~g})$ after overnight fast. -0 , rate of passage of lipid; $\mathrm{O}_{-}-\mathrm{O}$, concentration of lipid in digesta.

On the high-fat diet the pattern of lipid flow in the jejunum (Fig. $3 d$ ) was similar to that observed in the duodenum of pig 123 on the same feeding regime (Fig. 2). The concentration of lipid in the jejunum was lower, however, and less subject to the fluctuations observed in the duodenum. A maximum flow of lipid of $125 \mathrm{mg} / \mathrm{min}$ was recorded $30 \mathrm{~min}$ after ingestion of the single meal. On the low-fat diet, the peak flow of lipid in the jejunum increased less markedly than on the high-fat diet, and had a maximal value of about $27 \mathrm{mg} / \mathrm{min}$ (Fig. $3 c$ ). 


\section{Uptake of lipid from a jejunal loop}

In a preliminary experiment it was established that mixing of the contents of the loop occurred within $10 \mathrm{~min}$ from the start of perfusion. In all subsequent experiments, the mean of the concentration obtained after complete mixing had occurred was used to calculate the rate and degree of uptake.

Table $\mathrm{x}$. Effect of flow rate on the uptake of micellar $\left[\mathrm{I}-{ }^{14} \mathrm{C}\right]$ oleic acid from an intestinal loop in the pig (pig $\mathrm{I} 40$ )

\begin{tabular}{|c|c|c|c|c|}
\hline $\begin{array}{l}\text { Flow rate } \\
(\mathrm{ml} / \mathrm{min})\end{array}$ & $\underset{(\min )}{\text { Sampling time }[\mathrm{I}-\mathrm{z}}$ & $\begin{array}{l}\text { Exit rate of } \\
{ }^{34} \text { Cloleic acid } \\
(\mathrm{mg} / \mathrm{min})\end{array}$ & $\begin{array}{l}\text { Rate of uptake } \\
(\mathrm{mg} / \mathrm{min})\end{array}$ & $\begin{array}{c}\text { Uptake of } \\
\text { total substrate } \\
\text { entering loop } \\
(\%)\end{array}$ \\
\hline $2 \cdot I$ & $\begin{array}{l}34 \\
41 \\
50 \\
60\end{array}$ & $\left.\begin{array}{l}r \cdot 34 \\
r \cdot 32 \\
I \cdot 05 \\
I \cdot 15\end{array}\right\}$ & $0.92 \pm 0.14$ & $42 \cdot 1 \pm 6 \cdot 5$ \\
\hline $4 \cdot 3$ & $\begin{array}{l}12 \\
16 \\
21\end{array}$ & $\left.\begin{array}{l}2 \cdot 44 \\
2 \cdot 59 \\
2 \cdot 71\end{array}\right\}$ & $\mathbf{I} \cdot 8 \mathbf{1} \pm 0 . \mathbf{I} 3$ & $4 \mathrm{I} \cdot 2 \pm 3 \cdot 0$ \\
\hline 10.5 & $\begin{array}{r}8 \\
9 \\
10\end{array}$ & $\left.\begin{array}{l}7 \cdot 27 \\
7 \cdot 16 \\
7 \cdot 29\end{array}\right\}$ & $3.50 \pm 0.07$ & $32 \cdot 4 \pm 0.6$ \\
\hline
\end{tabular}

Table 2. Effect of concentration on the uptake of micellar $\left[\mathrm{I}^{14} \mathrm{C}\right]$ oleic acid from an intestinal loop in the pig (pig 146 ; flow rate $4.3 \mathrm{ml} / \mathrm{min}$ )

$\begin{array}{ccc}\begin{array}{c}\text { Concentration of } \\ \text { micellar perfusate } \\ (\mathrm{mg} / \mathrm{ml})\end{array} & \begin{array}{c}\text { Rate of uptake } \\ (\mathrm{mg} / \mathrm{min})\end{array} & \begin{array}{c}\text { Absorption } \\ (\%)\end{array} \\ 0.1 & - & - \\ 0.3 & 0.36 & 28.2 \\ 0.6 & 0.66 & 25.5 \\ 0.8 & 0.72 & 20.9 \\ 1.0 & 0.96 & 22.2 \\ 1.5 & 1.40 & 21.5 \\ 2.0 & 2.50 & 29.1\end{array}$

Expt $\mathrm{x}$. Effect of flow rate on the uptake of micellar $\left[\mathrm{I}^{14} \mathrm{C}\right]$ oleic acid from the loop. $\left[{ }^{1}{ }^{14} \mathrm{C}\right]$ oleic acid $(1.02 \mathrm{mg} / \mathrm{ml} ; 5 \mu \mathrm{c})$ in micellar solution was perfused through the loop at three different flow-rates, the loop being washed out with about $500 \mathrm{ml}$ of normal saline between each perfusion. The results are given in Table I. As the flow rate was increased from $2 \cdot 1$ to $4.3 \mathrm{ml} / \mathrm{min}$, the uptake of oleic acid rose proportionately. However, when the flow rate was increased to $10.5 \mathrm{ml} / \mathrm{min}$ the increase in uptake was proportionately less (Table I).

Expt 2. Effect of concentration on the uptake of a micellar solution of $\left[\mathrm{I}-{ }^{14} \mathrm{C}\right]$ oleic acid from the loop. A micellar solution of $\left[\mathrm{I}^{-14} \mathrm{C}\right]$ oleic acid $(2 \mathrm{mg} / \mathrm{ml} ; 2 \mu \mathrm{c})$ was serially diluted with $0.5 \%$ sodium glycodeoxycholate-buffer solution to give a range of concentrations. PEG was added to each solution at a concentration of $7.5 \mathrm{mg} / \mathrm{ml}$. Each 
solution was perfused through the loop at a constant flow rate of $4.3 \mathrm{ml} / \mathrm{min}$ and the loop washed out thoroughly after each perfusion. Results are given in Table 2.

Rate of uptake was directly proportional to the concentration of oleic acid in the perfusate. Within the concentration range examined, no effect of concentration on the efficiency of absorption was observed.

Expt 3. Uptake of emulsified $\left[\mathrm{I}^{14} \mathrm{C}\right]$ oleic acid. In previous experiments in vivo with labelled triolein as the particulate substrate it proved impossible to eliminate lipase activity within the loop. In order to avoid any ambiguity introduced by such hydrolysis, oleic acid was used as particulate substrate in this experiment. It was prepared in emulsified form in the absence of bile salt to avoid micelle formation.

The emulsion was examined by phase-contrast microscopy before and after the experiment. Before the perfusion began, the perfusate was circulated through the system to allow equilibration with the walls of the tubes and reservoir. Samples were then taken at intervals from the inlet cannula in order to obtain representative values for the substrate entering the loop over the period of perfusion.

The concentration of oleic acid $(0.24 \mathrm{mg} / \mathrm{ml})$ at the input cannula indicated that a considerable amount of settling-out or adsorption of the emulsion, or both, occurred before entry to the loop. This was confirmed by microscopic examination of the perfusate, the material entering the loop showing a marked absence of the larger particles present in the freshly prepared emulsion. The radioactivity of the perfusate, however, declined to a plateau value after about $30 \mathrm{~min}$ and at this time it was considered that equilibrium was established.

The mean rate of flow of oleic acid into the loop was $I \cdot I 2 \pm 0.25 \mathrm{mg} / \mathrm{min}$ and its rate of exit $\mathrm{I} \cdot 04 \pm 0.20 \mathrm{mg} / \mathrm{min}$. The apparent uptake of particulate oleic acid was small (0.08 $\mathrm{mg} / \mathrm{min})$.

Expt 4. Uptake of a physiological micellar solution of labelled lipid by the isolated loop. The labelled micellar solution, isolated from intestinal contents as described above, was perfused through the loop using pig I 40 at a flow rate of $4.3 \mathrm{ml} / \mathrm{min}$.

The rate of uptake of $\left[{ }^{3} \mathrm{H}\right]$ oleic acid was $10.32 \pm \mathrm{I} \cdot 03 \mathrm{mg} / \mathrm{min}$, and the percentage absorption $49^{\circ} 4 \pm 4^{\circ}$. The rate of uptake of naturally derived micelles, when adjusted to the same input concentration, was similar to that of micellar oleic acid in Expt $I$, at the same flow rate, i.e. $2 \cdot 12$ and $\mathrm{I} \cdot 8 \mathrm{I} \mathrm{mg} / \mathrm{min}$ respectively at an input concentration of $\mathrm{I} \mathrm{mg} / \mathrm{ml}$ and flow rate of $4.3 \mathrm{ml} / \mathrm{min}$.

In this experiment the PEG dilution factor was less than unity, i.e. uptake of fluid had occurred.

Expt 5. Uptake of $\left[\mathrm{I}^{\mathrm{14}} \mathrm{C}\right]$ oleic acid and $\left[{ }^{3} \mathrm{H}\right]$ stearic acid in mixed micellar solution. A mixed micellar solution for perfusion was prepared from $\left[\mathrm{r}-{ }^{14} \mathrm{C}\right]$ oleic acid $(0 \cdot \mathrm{I} \mathrm{mg} / \mathrm{ml}$; $5 \mu \mathrm{c})$ and $\left[9-10^{3} \mathrm{H}\right]$ stearic acid $(0 \cdot \mathrm{I} \mathrm{mg} / \mathrm{ml} ; 5 \circ \mu \mathrm{c})$, and perfused through the loop at $4.3 \mathrm{ml} / \mathrm{min}$, using pig 146 . After completing the perfusion the loop was washed out with $50 \mathrm{ml}$ normal saline and the washings were collected, centrifuged for $10 \mathrm{~min}$ and the shed cells recovered. This procedure was repeated at intervals for a further $24 \mathrm{~h}$. After further washing, and homogenization in chloroform-methanol $(2: \mathrm{r}, \mathrm{v} / \mathrm{v})$, the ratio of ${ }^{3} \mathrm{H}$ to ${ }^{14} \mathrm{C}$ activity in the mucosal cell lipid was estimated.

The ratio of ${ }^{3} \mathrm{H}$ to ${ }^{14} \mathrm{C}$ in perfusate entering the loop was $\mathrm{Ir} \cdot 0$ and the mean value 
for this ratio in perfusate leaving the loop, obtained with five separate samples taken at the posterior cannula, was $\mathrm{II} \cdot 5 \pm 0.4$. The percentage absorptions of stearic and oleic acids were $23 \cdot 8 \pm 4 \cdot 5$ and $28 \cdot 6 \pm 5^{\circ} 0$ respectively. The ratio of ${ }^{3} \mathrm{H}$ to ${ }^{14} \mathrm{C}$ in the lipid of shed mucosa was $10 \cdot 4,9 \cdot 5$ and I I.2 after I, 8 and $2 \mathrm{I}$ h respectively.

Table 3. Relative uptake by an intestinal loop in the pig of $\left[\mathrm{I}^{14} \mathrm{C}\right]$ lauric, $\left[\mathrm{I}^{14} \mathrm{C}\right]$ myristic, $\left[\mathrm{I}^{14} \mathrm{C}\right]$ palmitic and $\left[\mathrm{I}^{14} \mathrm{C}\right]$ stearic acids from mixed micellar solution (pig 146 ; flow rate $4.3 \mathrm{ml} / \mathrm{min}$ )

\begin{tabular}{|c|c|c|c|c|c|c|}
\hline \multirow[b]{2}{*}{ Fatty acid } & \multirow{2}{*}{$\begin{array}{l}\text { Proportional } \\
\text { activity in } \\
\text { perfusate } \\
(\%)\end{array}$} & \multicolumn{4}{|c|}{ Proportional activity $(\%)$ in loop effluent at: } & \multirow{2}{*}{$\begin{array}{c}\text { Absorption } \\
(\% ; \text { mean } \pm \mathrm{sD})\end{array}$} \\
\hline & & $13 \min$ & $20 \mathrm{~min}$ & $30 \mathrm{~min}$ & $45 \mathrm{~min}$ & \\
\hline Lauric & $22 \cdot 7$ & $20 \cdot 6$ & $21 \cdot 8$ & $21 \cdot 9$ & 20.9 & $31 \cdot 2 \pm 6 \cdot 4$ \\
\hline Myristic & $22 \cdot 8$ & $22 \cdot 8$ & 22.5 & $23 \cdot 0$ & $23 \cdot I$ & $27 \cdot 0 \pm 5 \cdot 5$ \\
\hline Palmitic & $30 \cdot 7$ & $30 \cdot 3$ & 30.5 & 30.4 & $3^{I} \cdot 3$ & $27 \cdot 6 \pm 5 \cdot 6$ \\
\hline \multirow[t]{7}{*}{ Stearic } & $23 \cdot 8$ & $26 \cdot 3$ & $25^{\cdot I}$ & $24 \cdot 7$ & $24 \% 7$ & $23.3 \pm 3.3$ \\
\hline & \multicolumn{6}{|c|}{$\begin{array}{l}\text { Proportional activity }(\%) \\
\text { in shed cells after: }\end{array}$} \\
\hline & \multicolumn{2}{|c|}{ Fatty acid } & I h & $3 \mathrm{~h}$ & $5 \mathrm{~h}$ & \\
\hline & \multicolumn{2}{|c|}{ Lauric } & $8 \cdot 8$ & $2 \cdot 9$ & - & \\
\hline & \multicolumn{2}{|c|}{ Myristic } & 29.9 & $21 \cdot 7$ & I I 3 & \\
\hline & \multirow{2}{*}{\multicolumn{2}{|c|}{$\begin{array}{l}\text { Palmitic } \\
\text { Stearic }\end{array}$}} & $3^{6 \cdot 1}$ & $43^{\prime} 7$ & $50 \cdot 4$ & \\
\hline & & & $25 \cdot 2$ & $3 I \cdot 6$ & $38 \cdot 2$ & \\
\hline
\end{tabular}

Expt 6. The relative uptake of $\left[\mathrm{I}^{14} \mathrm{C}\right]$ lauric, $\left[\mathrm{I}^{14} \mathrm{C}\right]$ myristic, $\left[\mathrm{I}-{ }^{14} C\right]$ palmitic and $\left[\mathrm{I}^{14} \mathrm{C}\right]$ stearic acids in mixed micellar solution. In this experiment equimolar proportions of $\left[\mathrm{I}^{14} \mathrm{C}\right]$ lauric $(8.5 \mathrm{mg} ;$ Io $\mu \mathrm{c}), \quad\left[\mathrm{I}-{ }^{14} \mathrm{C}\right]$ myristic $(9.6 \mathrm{mg} ;$ Io $\mu \mathrm{c})$, $\left[\mathrm{I}^{14} \mathrm{C}\right]$ palmitic $(10.8 \mathrm{mg} ; 10 \mu \mathrm{c})$ and $\left[\mathrm{I}^{14} \mathrm{C}\right]$ stearic acid $(12.0 \mathrm{mg} ; \mathrm{IO} \mu \mathrm{c})$ in $25^{\circ} \mathrm{ml}$ of bile salt-phosphate buffer solution were perfused through the isolated loop (pig I46). The shed mucosal cells were examined at intervals as in the previous experiment.

There was virtually no change in the proportional activity of the fatty acids which entered and left the isolated loop (Table 3). The mean percentage absorption of each fatty acid calculated from these values is given in Table 3 ; there were no significant differences between them. On the other hand there was a tendency for the longerchain fatty acids (palmitic and stearic) to accumulate in the shed cells, at the expense of the shorter-chain fatty acids.

\section{DISCUSSION}

The modified perfusion system used in these experiments had several advantages over the continuous re-circulation system used in previous experiments (Freeman et al. 1967). It was more sensitive in that changes in perfusate concentration brought about by uptake from the loop were not obscured by dilution in a reservoir, and moreover percentage absorption, probably the most useful measurement of uptake for comparative purposes, was not affected by loss due to leakage. Since input concentration and flow remained constant, the assay of efflux samples after equilibrium had been attained in the loop was essentially replication, and thus an estimate of experimental variation was obtained. 
The absorption of micellar lipid, prepared in vitro or isolated from intestinal contents, was considerable, namely about $40 \%$ in pig 140 and about $30 \%$ in pig 146. By contrast, the uptake of particulate lipid was small, even allowing for the greater error involved in its determination. The apparent uptake observed, in fact, represented the uptake of particulate lipid by true absorption, adsorption, and possibly by deposition on the mucosal surface of the loop.

As in the experiments in vitro (Freeman et al. 1967), no significant specificity was observed in the uptake of fatty acids when present in equimolar concentration in mixed micellar solution. There was an indication that at the greater extent of absorption attained in vivo $(\sim 40 \%)$ compared with in vitro $(\leqslant 10 \%)$, a small preferential uptake of lauric acid relative to stearic acid occurred. This was in contrast to the marked specificity in the rate (lauric $>$ palmitic $>$ stearic) at which these fatty acids were incorporated into mucosal triglycerides (Freeman et al. 1967). It was noticeable that those fatty acids which were incorporated relatively slowly into mucosal triglycerides were found in increasing proportion in the cells shed from the intestinal loop several hours after termination of perfusion of the loop.

The amount of micellar lipid taken up by an intestinal loop in a given time was. clearly dependent on the concentration and the rate of flow of the micellar solution. Although the rate of uptake varied linearly with the concentration of lipid presented to the intestine at a given flow rate, the efficiency with which it was taken up remained unchanged, i.e. percentage absorption was independent of concentration. We have observed this same independence in experiments in vitro using intestinal rings, although uptakes were much reduced in this system.

On the other hand, changes in flow rate had an appreciable effect on the efficiency of absorption of lipid by the intestinal loop. Thus at flow rates of 2-4 $\mathrm{ml} / \mathrm{min}$ absorptive efficiency was about $30 \%$ higher than at $10 \mathrm{ml} / \mathrm{min}$. Whether a similar situation holds for absorption from digesta in the intestine of the intact animal is not known. The rate of flow of digesta, as determined by the re-entrant fistula technique, is however known to vary considerably under different feeding regimes (Noakes, Hill, Freeman \& Annison, 1967). Periods of intensive flow were observed following the ingestion of single meals, and under these circumstances absorptive efficiency may be reduced. However, the technique of using re-entrant fistulas to measure rate of flow precluded any assessment of the extent of reverse flow which is certainly a characteristic feature in the intestine of the pig and which may markedly reduce the apparent net onward flow as measured by this technique.

There seems to be little likelihood, however, that the capacity of the small intestine of the pig to absorb micellar lipid is normally ever exceeded. If the absorptive capacity of the intestinal loop is extrapolated to the whole of the proximal small intestine, an approximate value for the absorption of micellar lipid from the tract of $250 \mathrm{mg} / \mathrm{min}$ from a solution of $5 \mathrm{mg} / \mathrm{ml}$ and at a flow rate of $4 \mathrm{ml} / \mathrm{min}$ is obtained for pigs of approximately $30 \mathrm{~kg}$ body-weight. In pigs of similar weight, fed a high-fat (10\%) diet ad lib., the amount of lipid entering the jejunum at a similar flow rate and concentration was observed to be $40 \mathrm{mg} / \mathrm{min}$. This value is obviously much below the estimated capacity of the tract to absorb lipid. Even during periods of intensive digesta flow 
following the ingestion of a single meal of high fat content, the influx of lipid to the small intestine rarely exceeded the estimated absorptive capacity. In this context it must be emphasized that not all of the intestinal lipid to which the fat-flow values refer is in the preferred absorptive form, i.e. as micellar lipid. Kvasnitskii (195I) has drawn similar conclusions in relation to carbohydrate absorption by the small intestine of the pig and it is evident that intestinal absorptive capacity is not the limiting factor in lipid and carbohydrate assimilation.

We are grateful to Mr D. R. Best for technical assistance and to Miss H. Yeates for assistance with the experimental animals.

\section{REFERENCES}

Blankenhorn, D. H. \& Ahrens, E. H. Jr (1955). F. biol. Chem. 212, 69.

Borgström, B. (1967). Proc. Nutr. Soc. 26, 34.

Borgström, B., Lundh, G. \& Hofmann, A. F. (1963). Gastroenterology 45, 219.

Downes, A. M. \& McDonald, I. W. (1964). Br. F. Nutr. 18, 153.

Freeman, C. P., Annison, E. F., Noakes, D. E. \& Hill, K. J. (1967). Proc. Nutr. Soc. 26, vii.

Hofmann, A. F. \& Borgström, B. (1962). Fedn Proc. Fedn Am. Socs exp. Biol. 21, 43.

Hofmann, A. F. \& Borgström, B. (1964). F. clin. Invest. 43, 247.

Hydén, S. (1956). K. LantbrHögsk Annlr. 22, 139.

James, A. T. \& Piper, E. A. (1963). Analyt. Chem. 35, 515.

Kvasnitskii, A. J. (I95I). In Voprosy fiziologii pishchevarenija u svinej. Moscow: Sel 'Khozgiz.

Noakes, D. E., Hill, K. J., Freeman, C. P. \& Annison, E. F. (1967). Proc. Nutr. Soc. 26, vi.

Somogyi, M. (1945). F. biol. Chem. 160, 69.

Ulyatt, M. J. (1964). N.Z. Fl agric. Res. 7, 713. 